\title{
FACING DIFFERENCES AS RESOURCE OF HARMONY: A CASE IN BANGUNTAPAN
}

\author{
Moch. Ichiyak Ulumudin* \\ ichyak1988@gmail.com
}

\begin{abstract}
Abstrak
Indonesia salah satu negara yang heterogen dan menyimpan berbagai macam keragaman, berupa bahasa, suku, tradisi bahkan agama.. Perbedaan agama dalam beberapa kasus sangat rentan terhadap konflik seperti: yang pernah terjadi di poso dan ambon. Namun, perbedaan agama tidak akan melahirkan konflik keagamaan jika, mampu mengelola dengan baik sebagaimana terdapat di desa Plumbon, Banguntapan, Bantul, Yogyakarta. Di wilayah tersebut, terdapat tiga agama yang berbeda yaitu Islam, Hindu, Kristen dan Katolik. Meskipun demikian, mereka dapat hidup rukun dalam perbedaan tersebut. Kerukunan agama di Banguntapan terbentuk melalui dialog interaktif yang terbingkai dalam perayaan, tradisi dan upacara keagamaan. Masing-masing Agama terdapat perayaan/ upacara keagamaan yang dimanfaatkan oleh warga yang berbeda agama sebagai ajang dialog dengan ikut berpartisipasi didalamnya sebagai bentuk penghargaan terhadap agama lain sekaligus mendukung dan mengkondisikan situasi perayaan. Pada sisi lain dukungan juga dalam bentuk finansial, moral dan upaya-upaya untuk menemukan sinergitas/ keseimbangan antar umat beragama. Keunikan di desa Banguntapan adalah pada tradisi upacara keagamaan yang dianggap masyarakat setempat bernilai sangat sensitif terhadap kegiatan-kegiatan ritual antar agama.
\end{abstract}

Kata kunci : Perbedaan Agama, Kerukunan Antarumat Beragama, Tradisi Keagamaan.

\section{Abstract}

Indonesia is one of the heterogeneous countries and has various diversity of language, ethnicity, tradition, and religion. Religious differences in some cases are very vulnerable to conflicts such as those that have happened in Poso and Ambon. However, religious differences will not necessarily lead to religious conflicts if it is the case in Plumbon, Banguntapan, Bantul, Yogyakarta. In the region, there are three different religions: Islam, Hinduism, Christianity and Catholicism. Nevertheless, they can live in harmony in these differences. Religious harmony in Banguntapan is formed through an interactive dialogue framed in celebrations, traditions and religious ceremonies. Each Religion is a religious ceremony. The celebration or ceremony serves as a means of dialogue by participating in it as a form of appreciation of other religions as well as supporting and conditioning the situation of celebration. On the other hand, supports are also in the form of financial, moral and efforts to find synergy or balance among religious people. The uniqueness in Banguntapan village is in the tradition of religious ceremonies that local people consider highly sensitive to interfaith ritual activities.

Keywords: Religious Difference, Religious Harmony, Religious Rituals.

\section{INTRODUCTION}

In a diverse society, the challenge of a harmonious society is usually harder. Differences tend to conflict. Horizontal conflict in many cases happened due to difference of ethnicity, religious background, economic level, or difference social and political ideology. Promoting a harmonious relationship in a diverse society is important to human being

* Lembaga Pengkajian Agama dan Masyarakat, UIN Sunan Ampel Surabaya as homo-socious. Without it, diversity always becomes evil rather than a good resource for social life.

One of the differences, which nowadays challenge harmony, is the difference of religious background. In a diverse society, including Indonesia, which has several religious backgrounds, making a harmonious society without making harmony between religions seems impossible. To come to a harmonious society, the difference of religious 
background should be in harmony. It indeed is not something easy to create or construct harmony among diversity specially in religious matter.

Harmony between religious occurred in the relationship among its member in the society. Looking at the life of the society in Banguntapan, Bantul, Yogyakarta, religious harmony is ingrained within society bond by religious, social, and cultural values. There are three religions in Banguntapan, namely Islam, Hindu, and Christianity, especially Catholic. People in Banguntapan live together in harmony for many years. They closed to each other, practice their religious practices, and do social activities together.

People in Banguntapan do not only live together and unite in doing social activities, but also support one each other in their religious practices. They help other while others doing religious practices, such as helping people in Pura or Masjid. In some cases they also do religious practices together which has become a tradition in that places, such as Selametan, Nyadran, and others. Social activities such as working together (Kerja Bakti), SISKAMLING, in the villages also unite them into one society to build harmony.

Looking carefully at the practices in Banguntapan, religious dialogue occurred in the daily activities without learning the teaching of other religions carefully. Harmony that happened from the practice is a result of tight relationship bond in the same understanding of the humanity who has a social concern, live from the spirit inherited in their own culture, and grow in the spirit of their religion. Those three motives strengthen their relationship. There are forms and attempts to maintain harmony in society, through activities that involve all residents through the various areas of activity, such as religious activities; religious feast, social; mutual assistance, SISKAMLING and other activities. This study further examines the biography/history intersections of the inter-religious interaction. ${ }^{1}$ There is a

${ }^{1}$ Charles W. Mills, The Sociological imagination, (New York: challenge and the struggle they face in religious differences, and the process of building a tolerance to achieve a harmony in aligning the different identity.

Religious life of Indonesian society often becomes actual discoursing on scholar circle. This is because there are several social issues involving religion as fundamental motive referring the issues. Religion is like a tool of legitimation in approving some actions done by certain religious group negatively. Otherwise, religion also contributes in establishing religious harmony among different religious believer. In this case, rreligion is like a coin which had double face in contradictive point of view. In the one hand, religion is capable to establish a conflict and in other hand, it can be a source of peace, harmony among people of different religion.

Inter-religious relationship of Indonesian people becomes an important matter that should be concerned a lot. Reality of Indonesia people shows that religious sentiment between inter-religious followers emerges a conflict between them. Azumrdi azra identifies some factors that influencing religious sentiment; they are economic, education, access, politic, ethnic, cultural background, geography and history. ${ }^{2}$ However, this kind of matters depends on how people understand religion. If all people understand diversity as something positive then a harmony among inter-religion will be born as well as what have happened on Plumbon village in Yogyakarta regency.

In this place, the society consists of different religious background that is Hindu, Islam and catholic. In spite of these backgrounds are different but they live in harmony with respecting each other. This is a kind of circumstance that supposed to be kept in mind for other society in Indonesia. Thus, religious conflict and social disunity can be eradicated to make a peace.

\footnotetext{
Oxford University Press, 1959).

2 Azyumardi Azra, Konteks Berteologi di Indonesia:

Pengalaman Islam, (Jakarta: Paramadina, 1999), p. 29.
} 
In such matter, Inter-religious life sometime gives negative and positive impact for people within. In several places in Indonesia, inter-religious life often experiences awful condition. It has been recorded that there are many conflicts, which had been resulted from different religion encounter. Poso and Ambon tragedy are for example in which polemic happened is between Islam and Christian. In this place, inter-religious life between different religions is in serious condition. Nevertheless, in other places, interreligious life on the contrary is maintained well for instance in Banguntapan sub-district, Yogyakarta regency. In this place, the situation of inter-religious life has been preserved and become main commodity on the society which people from different religion can implement religious practice in accordance with their belief system.

\section{INTER-RELIGIOUS LIFE IN PLUMBON VILLAGE}

Plumbon one of the villages in Yogyakarta has three different kind of religious background in one place. In this place, Hindu, Islam, and Catholic people can live together and practice their faith as free as possible. Despite, there three different religious backgrounds, the people never problematize about it and instead people, from one religion, support other religions in doing religious practices in accordance with their religious teaching. For instance, Muslim appreciates Hindu's people when held Pagerwesi ritual in Pure (Hindust worshipping place) and Muslim people gave full support and help them by providing parking lot.

However, issues about religious conflict do not influence them; as the result, interreligious life among people is preserved well. One recent solution offered on this issue is giving them more understanding in religious teaching that according to Pak Sastro (religious promoter from Hindu), religion should become the way in directing people to better life and welfare. ${ }^{3}$ Referring to this circumstance, Yuni Mogot Prahoro (an employee of Harian Umum Pikiran Masyarakat) stated that universally, religion constitutes one of human social life characteristic that means all religious followers have their own way in accordance with what they believe. ${ }^{4}$ Thus, those religious backgrounds are not a big deal which threatening inter-religious life in this place.

\section{INTER-RELIGIOUS HARMONY IN PLUMBON VILLAGE}

Hindu, catholic, and Muslim people respect each other as the way to create religious harmony among them. The religious harmony has been kept on their mind since long time ago and implemented until today and it is portrayed on their respond to other religions. In some activity held by village as well as SISKAMLING, Gotong royong, Kerja bakti, Arisan, and Commemorating the Independence Day, they did it each other without any problem about different religious background and respected each other. However, small things that could threat this harmony sometimes emerge, for instance; misinterpret something about religion doctrine but it is not a big problem which means it can be solved by giving more understanding about the problem. According to Pak Narno, religious figure from hindu, catholic and islam have an obligation in giving an understanding toward their religious follower in order to religious harmony can be continued. ${ }^{5}$ Quoted from Drs. Abdul Madjid, M.Ag in UMY Campus on Thursday (23/12) that harmonization between inter-religious followers can be done through developing their religious understanding. ${ }^{6}$ In this case, religious

${ }^{3}$ Pak Sastro, Personal Interview at 18:25, 14 March 2014 in his Place

${ }^{4}$ Pahoro, Yuni, Mogot, “Aplikasi teori tindakan komunikasi Hebermas dalam eksistensi kepercayaan terhadap tuhan yang maha esa: kasus masyarakat Cigugur, Kuningan Jawa Barat", in Journal Pikiran Rakyat, Volume 6 No. 2, (2010): 1.

${ }^{5}$ Pak Sunarno, Personal interview, at 16:30 14 March 2014 in Pure Banguntapan

${ }_{6}$ "Drs. Abdul Madjid, M.Ag on A workshop of "Penguatan Pranata Social Sebagai Agen Harmonisasi Kehidupan Umat Beragama" in Kampus Terpadu UMY at Thursday, 23 
harmony can be cultivated as long as people in heterogeneity respect and appreciate each other.

\section{PLURALISM IN PLUMBON VILLAGE}

Plumbon village practices religious pluralism as main concept of social life. According to Coward, pluralism is a phenomenon inevitably to be avoided. Human live in pluralism and are a part of pluralism, actively or passively, including religiosity. ${ }^{7}$ Religious plurality in Plumbon can be seen on its society meant there are more than one religion adhered which are hindu, islam and catholic. From this multi-religion, plumbon society is well known of its plurality. Cak nun statement on the book entitled of "Pluralism Borjuis Kritik Atas Nalar Pluralism Cak Nun" written by Nur Khalik Ridwan, explains that religious plurality is a concept of which affirmed that there only one fact of humanity that is heterogeneity and plurality. ${ }^{8}$ One of the concepts of pluralism in this place is that they live side by side with other religions cognitively and they realize that divergence is a part of Indonesia religious life. It was also said by Pak Sunarno that there is no divergence between other religion and all of them is in the same way to get peace into their live. However, truth claim which regarding that there is only one right religion will undermine pluralism values on their life. To prevent from this truth claim concepts, inter-religious dialogue has to be increased as the way of preventing. Thus inter-religious life, harmony and plural could be on going.

Plumbon's society keeps inter-religious relationship by respecting, appreciating, and helping the others. Inter-religious relationship in this context means social interaction between people from different religion. The people acknowledge that human have their

December 2010." Humas, UMY News, 03 January 2011, Media \& Advertising of UMY News. ac. id. Web. 17 March 2014

${ }^{7}$ Francis Clooney, "Contribution of Harold Coward to the Study of Religions and Hindu-Christian Studies", in Journal of Hindu-Christian Studies, Volume 15, Article 10 (2002): 5-6. Butler University Library, Web 18 March 2014

${ }^{8}$ Nur Khalik Ridwan, Pluralism Borjuis Kritik Atas Nalar Pluralism Cak Nun, (Yogyakarta: Galang Press, 2002), p. 77 own right in determining what is good for their life including religion. Religious freedom is a part of Plumbun social life that means there is no specific authority that could restrict human right in electing one of religions in Indonesia. Although there are small infractions within but the harmony of the people is not bothered. If the people can be tolerated, each other which means respecting other people from different faith and background, then everything will be better.

\section{TRADITIONAL EVENTS IN PLUMBON}

There are traditional events which are held by people in Plumbon. Nyadran and kenduren are Javanese tradition which has different order and characteristic. People in Plumbon keep maintain these traditions until now.

\section{a. Nyadran}

Nyadran is one of annual traditional rite which is held few days before Ramadhan. People in Plumbon come together from different religions (Islam, Christian and Hindu) to celebrate nyadran. The purpose of this rite is to pray for the relatives who were dead. This rite consists of visiting the graveyard, slametan, and praying. The uniqueness of nyadran is there will be some religious leaders who lead the prayer depend on their religion because this event is presented by people from different religious background.

As Beatty says, a crucial point of the sociology of the slametan is that the content of the address is roughly the same whatever the religious orientation of the speaker (a person who leads prayer). ${ }^{9}$ In Plumbon, it is done by the people in this village. As Ishak said, people in Plumbon maintain Javanese tradition; and nyadran is special rite that can make people in Plumbon live together in harmony and respectful each other; it is shown by the praying in the end of nyadran that is led by three different religious leaders in this village. The performance of slametan is recognized as

${ }^{9}$ Andrew Beatty, Varieties of Javanese Religion: an Anthropological Account, (Cambridge: Cambridge University Press, 1999), p. 46. 
having wider social benefits. It promotes a state of rukun among participants. ${ }^{10}$ Rukun which means both social harmony and the making of such harmony is the prime social value in village life. ${ }^{11}$ In everyday affairs it is achieved by the mutual adjustment of differing interests among fellow villagers. In the slametan, rukun is enhanced by two meanings: ${ }^{12}$ first, by the simple fact of taking part. Participation implies sharing the joys and sorrows of the occasion; it also requires a contribution to the costs and labor of a major feast, and ultimately a return invitation. Secondly, rukun is achieved by the form of the slametan itself. The need for rukun motivates participation in the slametan; and the syncretism of the slametan transforms ideological difference into rukun. ${ }^{13}$ Nyadran is combination between traditional and religious values by accept the new one without left the old one, so people in Plumbon keep maintain this rite as Javanese people. The interviewee says that by doing nyadran, people in that village get many benefits; it unites people from different religious background, it makes people there live in harmony and tolerance, and also gives benefits in economic aspect because of catering service of food for nyadran.

\section{b. Kenduren}

In Plumbon, people hold kenduren in unfixed time because it depends on the person who has hajat as the inviter. It is common event that is held by Muslim, Christian or Hindu in Plumbon. There is no difference in invitation of kenduren (even different background, religion, or social status) this event can make people sit together in harmony for certain address or intention of the inviter, for example birth, weddings, circumcision, funerals (three or seven or forty days of death), and other events. Something that unites the guests in kenduren is a momentary fictional kinship

\footnotetext{
${ }^{10}$ Clifford Geertz, The Religion of Java, (Glencoe: The Free Press, 1960), p. 61.

${ }^{11}$ Niels Mulder, Individual and Society in Java, (Yogyakarta: Gadjah Mada University, 1992), p. 40.

${ }^{12}$ Beatty, Varieties of Javanese Religion., p. 47.

${ }^{13}$ Beatty, Varieties of Javanese Religion., p. 47.
}

which signifies both common background and common humanity; any notion of a community of the faithful would only draw attention to the differences among participants. ${ }^{14}$

Beatty stated that slametan is the pattern of cultural compromise. ${ }^{15}$ People in Plumbon share the same tradition-Javanese valuethrough slametan and also nyadran in Plumbon. They come together to maintain their tradition. Actually the kenduren could be the slametan or the sedekah. The slametan is a rite for the living, and the last one is a prayer meal for the dead. ${ }^{16}$ Beatty has explanation about this rite as follow:

"The purpose of the slametan is to create a state of well-being, security, and freedom from hindrances of both a practical and spiritual kind-a state which is slamet. Although the word slamet can be used of the dead (in the sense of 'saved'), I was told on several occasions that the word slametan is inappropriate if uses of funeral feast, amounting to a solecism. Specific reasons for holding slametan include the celebration of rites of passage, housewarmings, and harvests; a wish to restore harmony after a marital or neighborhood quarrel, to safeguard a new motorbike or pain of oxen, to cancel the effects of a bad dream, and-among the commonest of reasons-to redeem a vow. But often there is no ostensible reason other than that one seeks the desired state of well-being." 17

Mark Woodward says that Javanese generally refer to both the social and psychological dimensions of slamet when asked to define it. ${ }^{18}$ In social discourse it refers to both mental states and social conditions. The individual is slamet when her or his mind is at rest, untroubled by worldly concerns or supernatural fears. This state does not suggest withdrawal from the world but, rather, the absence of strong emotions and acceptance of one's position in the social hierarchy.

${ }^{14}$ Beatty, Varieties of Javanese Religion., p. 36

${ }^{15}$ Beatty, Beatty, Varieties of Javanese Religion., p. 26

${ }^{16}$ Beatty, Beatty, Varieties of Javanese Religion., p. 30

${ }^{17}$ Beatty, Beatty, Varieties of Javanese Religion., p. 30-1

${ }^{18}$ Mark Woodward, Java, Indonesia, and Islam, (New York: Springer, 2011), p. 118. 
The community (however defined) is slamet when there is an adequate level of material prosperity together with an absence of social or political conflict. Javanese often state that two modalities of slamet are interdependent because psychological tranquility is possible only in well-ordered social contexts, while social harmony is possible only when the emotions of individuals are stilled. According to Ishak, people in Plumbon usually call slametan or sedekah as the same thing, namely kenduren. The form is same by inviting neighbors and relatives to come together, but different intention as mentioned before. It will bring benefits for people as inviter and also the guests in maintaining Javanese tradition, social and religious interactions, and hajat of people there.

\section{SOCIAL GATHERING IN PLUMBON}

The implementation of the social gathering conducted in Plumbon village is varied. This has been done since ages ago. These kinds of activities may be conducted in many other villages throughout Indonesia as well, but since the people in Plumbon village are quite multi-religious, the events held are perceived not to be homogeneous following one majority religion only.

The people in Plumbon village applied the philosophy of the existing religions such as respect, help, tolerance, and understand each other to build a harmony in society and this has been defined by Panikkar, "every cultural value has a definite sphere where it is valid and meaningful; any unwarranted extrapolation can only lead to confusion and misunderstanding,". ${ }^{19}$ The fact that they shared the same a local belief in the past supports this pluralism. They believe that every religion teaches its adherence to be a good person and it is understand if every religion has different dogma, but in this case they do not mix up the theology to interact with each other. Everyone's belief is a part of one's identity, pluralism is a part of society and people have

\footnotetext{
${ }^{19}$ Beatty, Varieties of Javanese Religion., p. 66.
}

to realise and understand it. They believe that all people are basically good people and if society supports it, this could build a harmony in society. These are some social events held regularly in Plumbon village.

\section{a. Gotong royong}

Gotong royong (mutual aid) is known as Indonesian term to define a voluntary and an unpaid work done together within members in a community. One of the examples of gotong royong without discriminating others is when the roof at the one of the mosques in Plumbon village was broken, the Hindu adherents fixed it. Not only they have skills in it but also it shows tolerance.

\section{b. Kerja Bakti}

Kerja Bakti is mostly defined as a working together to clean a village or some public places such as schools, religious places (for internal adherents) or a meeting hall. Sometimes Kerja bakti is not merely done for public places too, but around people's house as well. For example, on the weekend all people clean their houses along with their front yard. The leader of the village usually informs this to the people a few days before. This is a good activity to build a clean environment and people can interact with each other while cleaning their front yard.

\section{c. Being a committee}

Being a committee in this village means everyone is able to be a committee for some important events such as wedding, religious events, circumstances, funeral, etc. Being a committee is such a cultural activity that has been done from generation to generation. In a city if someone wants to hold a wedding ceremony and reception they use a wedding organizer to organise everything, they use caterer for the meal and rent a building for the guests. While in the village, the people still have a very close kinship. They ask their neighbour to help them to cook and prepare for the meal, arrange the event's round down and usually they do not need to rent a building or chairs for the guests 
because the chairs are available since the chairs are owned by the people in the village and a meeting hall is provided for people. To hold those events, usually it comes with a communal affair called "slametan." According to Beatty, "it is a ceremonial meal consisting of offerings, symbolic food, a formal speech, and a prayer,". ${ }^{20}$ Slametan is no longer practiced in a city or even in a homogenous village because they believe that it is not important or relevant to their life today, but in Plumbon village slametan is a big deal because the Selametan tradition was practiced by their ancestors and the people in Plumbon village still preserve that tradition. According to Beatty, "most people regard the Selametan as distinctively Javanese and pre-Islamic or even Hindu in inspiration,". ${ }^{21}$ The other events such as religious events, circumcisions and funeral have the same committee where the people are willing to help each other.

\section{d. Arisan}

Arisan is a social gathering done every month in a village. People gather and discuss about the current issue in the village. Arisan intends to make people to get to know each other, talk and arrange the next events will be held and build a social awareness. Arisan can be conducted more than once a month since there are many varieties of artisans, such as, arisan for women and men.

\section{e. Siskampling}

Siskampling is a men's voluntary unpaid work at night. They gather in a shelter called 'pos ronda' to watch over the village. Siskampling is no longer applied in a city. They ask a security officer to watch over their resident house because.

\section{f. Commemorating the Independence Day} Commemorating the Independence Day is celebrated by all Indonesian citizenship. Usually a day before, an event called Tirakatan is held. It is an event where people gather at night to pray together in

\footnotetext{
${ }^{20}$ Beatty, Varieties of Javanese Religion., p. 25.

${ }^{21}$ Beatty, Varieties of Javanese Religion., pp. 47-48.
}

multi-religious prayers and this is quite rare since mostly people tend to pray in Islam as the majority religion; some people make speech, deliver some performances such as dance, read poems, sing and many other performances relates to the Independence day.

Those events show that people in Plumbon village are more flexible and aware with the social changing but also are still keen to preserve their local culture that has been giving the philosophy of life and building a social stance. Moreover, those events represent Javanist value which according to Beatty, "everything practical endeavour, a reflection of experience, rather than as the finished work of experts". ${ }^{22}$

\section{RELIGIOUS ACTIVITIES IN TERMS OF INTERRELIGIOUS HARMONY}

To establish harmony in religious different society, people of plumbon take advantage of religious activities as a consideration to tightent interreligious harmony. One of the activities includes ogoh-ogoh celebration which held before Nyepi feast, halal bi halal, Christmas and two feasts of islamic and etcetera. In these kind of circumstances, people from a certain religion are involved to participate in the events. By participating in these activities, the contribution of other interreligious people contributes in forming tolerance and respect for the differences. The practices that performed every year became an event that in the end is owned and felt the togetherness for example muslim and even Christian feel involved and become part of the Hindu ceremony in the celebration of Ogohogoh. ${ }^{23}$ In appearance of the statue of Ogohogoh, it is illustrated as a horrible being or usually called mythical gigantic demon. The statue is then paraded circling around the

\footnotetext{
${ }^{22}$ Beatty, Varieties of Javanese Religion., p. 184.

${ }^{23} \mathrm{Ogoh}-\mathrm{ogoh}$ is a masterpiece of Balinese culture that represented Buta Kala's personality and Buta Kala consisted of two words; Buta (power) and Kala (Nature or Universe) that uncountable.
} 
village following by not only hindu people but also non-hindu people including Muslim and christian. One of the leaders, Pak sastro, even said that the adherence of each religion come to help when the feast day comes. It includes ogoh-ogoh ceremonial people from outside of the plumbon village even asking when the statue of ogoh-ogoh is going to be paraded.

This situation describes tolerance character of the interreligious people and the involvement of other people in following the religious ceremony also shows a good way to build inter-religious relations. Harmony and cooperation among them also look at every celebration of a religious feast. In iedul fitri for example, pak narno as hindu practitioner said that as an appreciation toward muslim in this village, we congratulate them as a way keeping harmonious relation among us and sometime when iedul adha we also get part of sacrificial animals meat.

As the above conversation, every Muslims feast which has become a tradition with the holding of the 'Halal bi halal' event as in general in various places, this event also involve people of all religions and not limited to the Islam people. In Banguntapan, the event is held on the Muslim side also open to the Hindus and Christians, all people are encouraged to attend the Halal bi halal.

The phenomenon of inter-religious harmony through involvement of other people in following events shows an interesting sight and raises a question, why do they want to be involved in the celebration of the feast or other religious activities. Some visible attitudes during the holidays emphasize the importance of maintaining good relations between religious communities as part of the Banguntapan people. One of the key factors that establish harmony in Banguntapan is the attitude of the openness between religions where people of different religions understanding each other and accept the existence of other people. Through the attitude of Banguntapan people towards differences is an inclusive attitude where this attitude needs to be shared by all people who are living in the middle of a difference, this is in line with Inclusivism theory proposed by Panikar, he said;

The most plausible condition for the claim to truth of one's own tradition is to affirm at the same time that it includes at different levels all that there is of truth wherever it exists. The inclusivity attitude will tend to reinterpret things in such a way as to make them not only palatable but also can be combined. ${ }^{24}$

Additionally, Panikar explained, this attitude has a certain quality of magnanimity and grandeur in it. You can follow your own path and do not need to condemn the other. You can even enter into communion with all other ways of life, and if you happen to have the real experience of inclusivity, you may be at peace not only with yourself, but with all other human and divine ways as well. You can be concrete in your allegiances and universal in your outlook. ${ }^{25}$

As Panikar's statement, to be able to feel peace within ourselves and in the environment where we live, inclusive attitude is needed to accept the differences where the attitude that feel has their own truth not limiting to interact with other people and not to judge, but to have tolerance and respect for others where they also feel has their own truth.

\section{THE FORMS OF INTER-RELIGIOUS UNDERSTANDING IN PLUMBON VILLAGE}

Inter-religious dialogue in Plumbon Village emerges in their daily life. The inter-religious dialogue in Plumbon Village takes varieties of expressions. The basic form of their interreligious dialogue is awareness of being other, tolerance, and social creative. Those aspects work together and build inter-religious dialogue in Plumbon Village.

\section{a. Awareness of being other}

The awareness that they have diverse belief and understanding in religious life is a basic view to build inter-religious dialogue.

${ }^{24}$ Raimon Panikar, The interreligious Dialogue: The Retoric of Dialogue, (New Jersey: Paulist Press, 1999), pp. 69-70.

${ }^{25}$ Panikar, The interreligious Dialogue., p. 7. 
The otherness shapes their daily life. Being other does not push them into different understanding about togetherness, but unite them into understanding of one to each other. ${ }^{26}$

Otherness and communion or unity seems incompatible and cannot be reconciled. Zizioulas gives his tremendous exploration on how being other did not come to separation but to unity. ${ }^{27}$ Otherness, Zizoulas said, is constitutive for unity. It is inconceiveble apart from relationship with other. Although he bases his theological scholarship on Orthodox church, his views is widely acceptable in ecumanical discussions.

Being other is a basic understanding in Plumbon Village. They are aware that they are different belief. Mr. Sastro Utomo said he comes from a Hindu family and he cannot avoid that others come from different background. This basic understanding that they are different comes from their understanding about themselves. In Zizioulas's words, the awareness of being other is based on anthropoligical conception of human being. This "conception can be summed up in one word: personhood". ${ }^{28}$

Personhood, in Zizioulas's view is understood in the relation between human person with his/her God, with himself, and others. First, as a person, human is always in relation with God. "The person is an identity that emerges through relatioship (schesis)..; it is an "I" that can exist only as long as it relates to a "thou" which affirms its existence and its otherness". ${ }^{29}$ People in Plumbon Village aware that they are always in relation with their God as they believe. This understanding is different with the understanding about individual. An individual is alone with him/herself, but a person is always in relation with other. Second, personhood is also a freedom to be the other.

${ }^{26}$ Following Zizioulas, the word otherness is used, instead of using word "difference". The word difference usullay consists of different quality, such as clever, beautiful, est. See John Zizioulas, (ed.), Communion and Otherness: Further studies in personhood and the church (London: T\&T Clark, 2006), p. 201.

${ }^{27}$ Zizioulas, Communion and Otherness., p. 201.

${ }^{28}$ Zizioulas, Communion and Otherness., p. 9.

${ }^{29}$ Zizioulas, Communion and otherness., p. 9.
Person implies to be him/herself. Seeing other as another also give a chance to other to be him/herself. Each person then is a unique person. In this sense a person is not an object of such norms or understanding, but a subject. The freedom is not "freedom from the other but freedom for the other". ${ }^{30}$ It is understood in Plumbon Village that they are aware to give a chance to others to grow in their own faith and at the same time they grow in their own faith as well. In this understanding, as Zizioulas said, freedom is identical with love. Third, based on the understanding to love others, personhood is creativity. A consequence of understanding of freedom as love, freedom is always for others. Otherness is always to do for others. In it obviously understood in Plumbon Village, people do social activities as their expression to do for others and as their way to express their personhood in the society.

\section{b. Tolerance}

Toleration is being practiced in Plumbon Village. Toleration in Plumbon Village is not only letting others to do their own religious practices but also supporting others in their religious practices. It is happened when one religion has a ceremony other members of religion will help and support them. In Plumbon Village when Hindu celebrates their religious occasion such as Pager Wesi or Ogohogoh celebration, they help others such as being tukang parkir, or help others. They also joint in their occasion so that they share their joy in celebrating religoius occasion.

Sharing joy and sharing religious occasion happened in some cases. For example when Muslim celebrates Idul Adha and share kurban that is meat, they will share the meat to Christians and Hindus. Christians and Hindus also come to the mosque to help Muslim in preparing the kurban. When Muslims celebrate Idul Fitri, Hindus and Christians also share their joy. They come to the Muslims house and congratulate them. When Hindus celebrate

${ }^{30}$ Zizioulas, Communion and otherness., p. 9. 
Ogoh-ogoh many people also come to watch the occasion.

Toleration which is practiced in Plumbon Village can be understood in difference points. As Susan Mendus summarizes the toleration understood by scholars from many differences. background, toleration can be understood in three parts, namely, first, toleration is a requirement of prudence, second, toleration is a requirement of rationality, third, toleration is a requirement of morality.

As a requirement of prudence is more than "merely living and letting live". It is involves cherishing those who have different background and perhaps those who dislike. In this understanding toleration in public keep order and stability. As prudence, toleration makes people in Plumbon Village do social relationship in a good manner. Toleration also supports them to help their neighboor when one of them has family occasion, such as wedding, circumcision, etc. As social prudence they live together as a community.

Toleration is also a requirement of rationality. When John Locke sees religious belief as an individual conscience, doing intolerant is irrational. Karl Popper sees that toleration can bring those who engage come to same understanding. Toleration can bring them to help other in understanding about something, correct of some mistake, and bring them nearer to the truth. ${ }^{31}$ People in Plumbon Village understand toleration as that rationality also. They see toleration is unavoidable need because they see others as others. When Mr. Sastro Utomo sees others have different religion he sees others is not similar with him; however have similar purpose in their life that is to come to salvation or peace. Toleration also can correct themselves in the society, such as when a leader wants to do working together (kerja bakti) together on the day Nyepi, toleration asked them to postpone the kerja bakti because Hindus would do Nyepi ritual.

${ }^{31}$ See further Karl Popper, The Open Society and Its Enemies, (London: Routledge, 1962).
Toleration in this experience becomes a soursce of understanding or spirit of understanding. Toleration is not only a condition, but something they create and give them support in living in plurality.

\section{c. Being Creative in Social Concern}

Social concern binds their daily life. People in Plumbon Village are active in their social concern such as in kerja bakti, siskamling, and helping their neighbors. This interaction comes from their understanding about themselves as a diverse community. In this sense, interreligious dialogue is understood. As Panikkar mentions about inter-religious dialogue, it is not philosophical or theological symposium, rather it is the unity in faith, hope, and love. ${ }^{32}$ In other way, social concern also manifests in religious tradition such as celebrating the feast day of religons. This is also what makes religious tradition in plumbon village unique. In dealing with religious feast, religious background is not a problem for they prioritize on preserving harmony upon everything. Common people in some places may have an objection when the feast day of their religion must be dealt with other religion. Iedul fitri and iedul adha for an example are sensitive thing in muslim perspective. Christmas also considers as special moment for christians and also nyepi events for hinduism. Those feast days are quiet important for three religious followers. However, Plumbon people consider the participation of the people from different religion is about to increase the relationship and harmonious level among interreligious people.

Likewise, when Muslims celebrate Idhul -Adha or the feast of sacrifice, both Hindus and Christians also helped contribute to the success of the event, such as helping skinning meat, and set the parking space. Not only helping the process of iedul qurban, muslim people also share the sacrificial meats to the hindu and christians people as form of social concern and interrelationship empowerment.

\footnotetext{
${ }^{32}$ Panikar, The interreligious Dialogue., pp. 69-70.
} 
In the next opportunity, the same way at the day of Nyepi, Muslims and Christians preserving the atmosphere that does not disturb the silence Hindus in celebrating Nyepi and congratulations on the next day. When the time come for the Christians celebrate Christmas, all the other people come to give congratulation.

This condition shows that religious hamony in Plumbon village involves social concerns of the people through religious tradition as a form of interreligious dialogue. In this regard, what the most important is that they can reach the same understanding of religious toleration.

\section{CONCLUSION}

Religious differences in Plumbon Village, Banguntapan, Bantul, Yogyakarta do not make people from different religious background being hostile and conflicting each other. Religious differences in Plumbon village instead create a pattern of harmonious relationship among religious communities. It can be seen from an attitude shown by people of Plumbon village in having relation among villagers through several activities such as the celebration of religious feasts, traditional events and social gathering such as Siskamling, Kerja Bhakti, Arisan and etcetera.

Those activities constitute an interreligious dialogue performed by Plumbon people in order to maintain harmonious condition in the village. Factors influenced in building harmony through interreligious dialogue base on some conditions such as; participation in any events bases on tradition, religious events, social gathering, and interreligious understanding of the people.

In such activities, people from different religious background are helping each other to get in touch with others uncaring about different religious faith among them. Hindu people for an example when the celebration of Christmas and Islamic feast comes, they visit Christians and muslim home in order to congratulate them personally. Otherwise for muslim and Christians when the celebration of nyepi (the holy day of hindu) comes, they visit hindus people to congratulate about nyepi celebration.

Beside of religious activities, traditional events such as selametan, halal bi halal and ogoh-ogoh ritual constitute kind of activities that are able to empowering relationship among people of Plumbon. Social gathering and village agendas such as arisan, siskamling and kerja bhakti also have contribution in managing religious harmony in Plumbon village. The impact of those activities is apparently seen in the forms of gotong royong (working togather) in a certain event. Interreligious relationship in Plumbon village then is formed from interreligious dialogue resulted from activities that are practiced and performed by Plumbon village in order to maintain differences of religious background in harmony. It thus religious differences is not something that must be addressed in dispute and hostile but friendship, kinship and helping each other as human beings.

\section{BIBLIOGRAPHY}

Azra, Azyumardi, Konteks Berteologi di Indonesia: Pengalaman Islam, Jakarta: Paramadina, 1999.

Beatty, Andrew, Varieties of Javanese Religion: an anthropological account, Cambridge: Cambridge University Press, 1999.

Clooney, Francis, "Contribution of Harold Coward to the Study of Religions and Hindu-Christian Studies", Journal of HinduChristian Studies: Volume 15, Article 10 (2002): 5-6. Butler University Library, Web 18 March 2014

Geertz, Clifford, The Religion of Java. Glencoe: The Free Press, 1960.

Humas, UMY News, 03 January 2011, Media \& Advertising of UMY News. ac. id. Web. 17 March 2014 
Mulder, Niels, Individual and Society in Java, Yogyakarta: Gadjah Mada University, 1992.

Madjid, Abdul, M.Ag on A workshop of "Penguatan Pranata Social Sebagai Agen Harmonisasi Kehidupan Umat Beragama" in Kampus Terpadu UMY at Thursday, 23 December 2010."

Mulder, Niels, Individual and Society in Java, Yogyakarta: Gadjah Mada University, 1992

Nur, Khalik, Ridwan, Pluralism Borjuis Kritik Atas Nalar Pluralism Cak Nun, Yogyakarta: Galang Press, 2002.

Panikar, Raimon, The interreligious Dialogue; The Retoric of Dialogue, New Jersey: Paulist Press, 1999.

Pahoro, Yuni, Mogot, “Aplikasi teori tindakan komunikasi Hebermas dalam eksistensi kepercayaan terhadap tuhan yang maha esa: kasus masyarakat Cigugur, Kuningan - Jawa Barat", Journal Pikiran Rakyat, Volume 6 No. 2, (2010): 1. Acta diurnA. Web. 16 March 2014.

Sastro, Pak, Personal Interview at 18:25, 14 March 2014 in his Place

Sunarno, Pak, Personal interview, at 16:30 14 March 2014 in Pure Banguntapan

Woodward, Mark, Java, Indonesia, and Islam, New York: Springer, 2011.

Zizioulas, John D., Paul McPartlan, and Rowan Williams. Communion and otherness: Further studies in personhood and the church (A\&C Black, 2006). 